ISSN: 2162-3104 Print/ ISSN: 2166-3750 Online

Volume 8, Issue 1 (2018), pp. 488-495

(C) Journal of International Students

http://jistudents.org/

doi: $10.5281 /$ zenodo. 1134353

\title{
Changing the Things I Cannot Accept: My African Experience of A U.S. Classroom
}

\author{
Roselyn Banda \\ Miami University, United States
}

\begin{abstract}
This article outlines the impact of cultural shock and my way of overcoming it as I migrated to the U.S. as an international student. Often-times, even in academia, where we learn to question and look at things from multiple angles, we essentialize subject positions and as a result silence, alienate and erase many people. Through the use of narrative, I am giving voice to my own struggles with silence and erasure inside of academia in the hopes that other scholars will consider their own complicity in this process and perhaps expand their own thinking and curriculum choices for the courses they teach. In addition, I hope to create space to build solidarity across difference both in and outside of the university.
\end{abstract}

Keywords: African women, transnational feminism, education, culture, culture shock, self-identity, erasure, stereotype, alienation

We do not describe the world we see, we see the world we know how to describe. - Peter Senge

\section{A (Dis)Connection between Africa and the Diaspora}

I crossed paths with an instructor from another department who taught me during my first semester of graduate studies after arriving in the United States in 2008. I had not seen her in two and a half years and we were so happy to reconnect. She asked for an update and I happily recounted my achievement. I informed her that I had finished my master's degree 
coursework and was currently enrolled in a doctoral program in Educational Leadership, and was weeks away from writing my comprehensive examinations. I explained that I was looking forward to earning my doctoral diploma. Suddenly she became serious and informed me that my academic achievements really impressed her. I began to mumble something about the whole experience being so much fun when she stopped me and said, "I am serious, considering that you come from Zimbabwe." I interpreted her wellintentioned, although disappointing comment, to mean that she was impressed that a Zimbabwean woman would get that far in an American university. She seemed to suggest that being a woman, a Zimbabwean, or an African, is incongruent with earning a doctoral diploma in the United States. As I started my graduate school journey in an American university, I could not help but notice the unstated and unacknowledged assumption about who I was and what position I should hold being an African woman.

My educational history had no barriers because my father valued and understood the need for education. My brothers and I were treated as equals. Schooling was challenging in that we had a lot of examinations to pass along the way. Our basic pedagogy was what Freire (1993) termed the banking system. Teachers in secondary and high school, and lecturers and teaching assistants at university transmitted to us the material we needed to master in order to pass these examinations. All I needed to do, and I did, was trust that the material I was getting from my teachers was correct, memorize it and I was rewarded with good grades.

\section{The Self: Belonging or Gaming}

Mead (1934) stated that "The self is something which has a development; it is not initially there at birth, but arises in the process of social experience and activity; that is, it develops in the given individual as a result of his/her relations to that process as a whole and to other individuals within that process" (p.135). When I was among my own people, the people I was related to through common culture and a sense of community, I was not so self-conscious about my identity. The art of communication and coordination came naturally because I was among familiar people, where I played my many roles of daughter, sister, wife, sister-in-law, daughter-inlaw, church member, friend, workmate, and host of others depending on my relationship with those with whom I communicated. Mead's (1934) theory of the self shows that as our world gets bigger and we move out of the organized community, and we don't relate as much to the people around us, the role-playing ceases, and we start gaming. The game that we start playing 
has positions assigned to us depending on who you are and how well you can play the game.

My construction of the self is now dependent on how others perceive me. Getting into a society where I look different, where I speak with an accent, and where my place of origin stigmatizes my being has made me reflect on who I am and for what I stand. My problem is the disconnection between what I know I can do and what my colleagues, who are privileged in so many ways, think they know what I am capable of doing. Because of who I am thought to be, and also because I am trying to understand myself through the eyes of others, a lot of assumptions and misconceptions arise. The end result is we fail to see through our commonalities so that we appreciate our differences.

Sometimes the effects of culture shock are so severe that the disorientation might unintentionally invite sympathy. I observed that when talking with American colleagues there seems to be a genuine ignorance about Africa and its people. As I prepared to write this essay by reflecting on my experiences since arriving in the United States, I could not help but wonder how sharing my interpretations and impressions of how I was received in the United States will be interpreted. I find it worthwhile to confront the sites and processes of domination as they affect my Zimbabwean identity in the United States. I write from the standpoint of my personal, specifically located experience. It is important to note that the experiences of other African women might differ from mine, but nonetheless illuminate important, undeniable commonalities. For many Africans who have never traveled abroad, America is that place where one's opportunity doors are open. Coming from a homogenous group in terms of race, as Africans, we rarely think about how our skin color relates to histories of race in America.

My first encounter with the reality of my "Africanness" was when a well-meaning lady, whom I felt I already knew through telephone and internet conversations, welcomed me to an "electric" kitchen. She was too happy to show me how to turn on the stove, what I could place in the fridge and deep freezer. She assumed this was my first contact with electricity. I discovered the true meaning of Third Worldism, a meaning beyond the slightest imagination of a person from Africa. As I struggled to challenge the problems of essentialism and the reality of differences, I realized the truth in Edward Said's notion of "flexible positional superiority" which alludes to Oyeronke Oyewumi's argument about imperialism as a metascript of domination and oppression, revealing itself variously in the realms of culture, nationality, race, ethnicity, gender and class. I found myself in 
the midst of a society that has a strong belief in the primitiveness and backwardness of Africa. A society that never ceased to be surprised that I, an African woman, was able to speak English. Oyewumi (2003) believes that the images of Africa in Western perspectives are made possible by the projection of a powerful myth of Africa as a homogenous, unitary state of primitivism. I was never expected to have encountered electricity in my life. I do not know why I was not expected to speak fluent English, even though history reveals that the English colonized most of Africa. So everywhere I went and spoke, it was ahhs and oohs of how I leaned English so quickly.

When I started my graduate school classes I must have been a sight because it seemed like most of my colleagues had not previously interacted substantively with an African woman at such close range. The zeal I had from my previous experiences, a good student, and an experienced administrator, made me believe that I could tackle any situation, especially this one. I participated in class sharing my life and professional experiences as well as beliefs. I noticed that my colleagues would just stare at me when I spoke, leaving it to the instructor to respond. Initially I thought that my colleagues felt it was not in their interest to discuss any issues outside their American context. I felt like I was not being viewed as an authentic source of knowledge. Through conversations I have realized that accent and pronunciation may also have played a part in the misunderstanding. Most Americans smile and nod to stay in that "safe harbor" where they do not have to be accountable for anything foreign to them.

My colleagues avoided conversations with me, in and outside of school, for fear of misunderstandings, a problem with which I was also wrestling. Class discussions were done in such a way that if I lost track, I would feel very unsure of whether to participate in the discussion or not, because if I missed the point and say something unrelated it would only serve to perpetuate the view that Africans were dull. I was not sure whether my colleagues were aware of their privileges, home country, a lifetime of experiences they felt were the norm, and a language they could articulate well. Would they step out of that comfortable location of privilege and accommodate an outsider?

\section{Curriculum Theory: Invisibility and Erasure}

Some of my instructors erased Africa through professing ignorance about the continent, making discussion about it stifled before it even began. Robert Kegan (1992) wrote of an ability to "resist" or tendencies to make "right" or "true" that which is merely familiar and "wrong" or "false" that 
which is only strange. Once something looks inauthentic, it becomes very difficult to pursue. I realized then that most of what I said in class would be responded to by a correction like "do you mean..." There is always a problem when people around you are more willing to correct you than listen to what you say. In such instances, even if I knew what I was talking about, I would not argue or be reactionary. Overtime my voice disappeared, and sitting in the classroom with instructors and colleagues I virtually became invisible. My colleagues and instructors interpreted my silence in many ways. The most common one being derived from my nationality, African, my gender, a woman and my race, black. I watched myself shrink from what I used to be, a confident administrator, to an image of a pre-school child on the first day of school.

I tried to find solace in the Women Studies Department, where I hoped that issues of women are looked at far beyond the commonalities we have as women to emphasize the differences- a multicultural approach that allows women to speak in their own culturally different voices. I became confident that as a woman I could find space in the Women Studies Department to be myself, and be accepted as such. I overlooked the fact that being African is a dilemma that is inescapable. When I was among other women, especially white women, I felt an invisibility that continuously reminded me of my "outsider-within" status (Collins, 2009). I found that I could be in that feminist space as an African woman but still not a member of the community. Bell Hooks (1989) noted that if one does not speak in a language that can be understood, then there is little chance for dialogue. My worry is that our differences obliterate the humaneness in us, and makes us weigh who is better than who and why, and that alone determines what conversations we can have.

One of my instructors believed she knew Africa more than me because she had visited Kenya on a few occasions. She was teaching an undergraduate seminar on women and development. The topic was on project development in Africa. She was enthusiastically explaining how those women with whom she worked in Kenya appreciated her expertise. She however mentioned that at times most projects collapse when the "expert" returned to their countries. The natives fail to sustain the projects, and she attributed it to lack of knowledge and probably poor work ethic. Being the only African in the class I pointed out that at times, expert outsiders imposed those projects on a people who were too busy doing what really mattered to them, which better sustained them. I went on to elaborate that there was need for consultation with the local people to understand their way of life, their needs and their priorities. She looked at me for a while, 
and then turned her attention to the class and said, "If you go there and talk to those people you will never get anything off the ground. We are the experts, and we know what those people need."

I discovered that the way in which the African woman is constituted, conceptualized and theorized in Western scholarship creates its own warped reality. The "curricularization" of African women in most classes is problematic because they are thrown into a course syllabus in order to take care of ethnicity, and class issues (Nnaemeka, 1994). They are also romanticized into an unexplored category, patiently waiting to be discovered and helped. This misrepresentation put me in a situation where I felt I had to counter everything I saw as not true. I have always wondered what makes articles African; the writer or the content? Walker (1992) wrote Possessing the Secret of Joy from her imagination of what Africans go through before, during and after clitoridectomy, popularly known as female circumcision. Pierre-Damien Mvuyekure in an undated blog titled Alice Walker's Colonial Mind, felt that Walker had "colonized" an African female body and endowed her African American characters with colonial/neocolonial attitudes towards Africa and the Africans. I recently read The Help written by Stockett (2009) which details the lives of black maids in the 1960s in Jackson, Mississippi and the white women for whom they worked. Through blogs it shows that some people seem disconcerted by the idea of Stockett, a white woman, writing, with a heavy dialect, in the voices of African American women. One blogger stated that "I want to read an African American version of The Help."

According to Chimamanda Adichie's video on The Danger of a Single Story, some of my class mates' views of the African woman were sometimes accurate, but incomplete. Adichie shows how having a single way to explain anything makes us overlook the many aspects of what a person can do or can be. The women they talked about in most of my classes were in their raw state, the typical rural African woman. As such, they did not illuminate what these same women had accomplished in the midst of their poverty, and patriarchal surroundings. That image of the woman I represented, the one who had been an administrator who had a private secretary, was missing in the picture. Telling them about this "type" sounded inauthentic because anything representing what they thought they knew, what they believed belonged to their standard of living becomes fictional and uninteresting. It ceases to be material for presentation.

Adichie speaks of how vulnerable and impressionable we become in the face of a story. Stories of women in other countries are told in such a way that it models who these people become. And our mental models are 
formulated and, in the long-run, cemented. We become closed to any other view, leading to teaching students about the image of the Other that we think we know. Nnaemeka (1994) points to how information management contributes to our construction of a notion of self and at the same time alienate us from the Other (p. 307). The stories that Americans know about African women, the content in the curriculum of some feminist classes as well as that "expertise" brought in by white women who have been to Africa, prove that the way the information is organized, ordered, and disseminated can undermine or promote alliances between and among women of different cultures. Acknowledging the fact that we "enter other cultures with our own cultural baggage" (Nnaemeka, 1994) will leave room for critical pedagogy.

\section{CONCLUSION}

Respecting another's culture does not mean that we agree with it, but that we understand the person's right to their own culture. In coming to voice, as bell hooks would say, I have discovered the beauty of understanding myself. Initially I was nervous about being assimilated into American culture and losing my identity. I have however, come a long way, and I have realized that to change is not often to lose my identity, but to find it. Curry (1998) stated that acknowledging the history and culture of others often enables us to know ourselves better. I hope that in our classrooms, we will get to a point where talking about African women and other international women is not so conclusive and final as to disregard lived experiences of those like me who have lived the life.

As Heifetz (1994) states, music teaches that dissonance is an integral part of harmony (p. 6). I have concluded that being reactionary and countering every misrepresentation will forever make Africa seen through the dungeon of history. My emotion and anger taught me that bridges cannot be built without first mobilizing the people to see the need for a bridge. The journey is still long, but meanwhile I should be able to tell my new American community who likes my accent that I like theirs too.

\section{REFERENCES}

Adichie, C. (2009, October 7). The danger of a single story. [Video]. Retrieved from http://www.youtube.com/watch?v=D9Ihs241zeg

Collins, P. H. (2009). Black feminist thought, knowledge, consciousness, and politics of empowerment. New York, NY: Routledge.

Curry, B. R. (1998). Transforming feminist theory and practice beyond the politics 
of commonalities and differences to an inclusive multicultural feminist framework. In K. Conway-Turner, S. Cherrin, J. Schiffman, \& K. D. Turkel (Eds.), Women's studies in transition: The pursuit of interdisciplinarity (pp. 76-91). Newark, NJ: University of Delaware Press.

Heifetz, R. (1994). Leadership without easy answers. Cambridge, MA: Harvard University Press.

Hooks, B. (1989). Talking back. Thinking feminist, thinking black. Boston, MA: South End Press.

Kegan, R. (1982). The evolving self: Problem and process in human development. Boston, MA: Harvard University Press.

Lorde, A. (1984). Sister outsider. New York, NY: Crossing Press.

Mead, G.H. (1934). Mind, self and society. Chicago, IL: Chicago University Press.

Nnaemeka, O. (1994). Bringing African women into the classroom: Rethinking pedagogy and epistemology. In Margaret R. Higonnet (Ed.), Borderwork: Feminist engagements with comparative literature (pp. 301-318). Ithaca, NY: Cornell University Press.

Nnaemeka, O. (2005). Mapping African feminisms. In Andrea Cornwall (Ed.), Readings in gender in Africa (pp. 31-40). Bloomington, IN: Indiana University Press.

Oyewumi, O. (2003). The white woman's burden: African women in Western feminist discourse. In O. Oyewumi (Ed.), African women and feminism: Reflecting on the politics of sisterhood (pp. 25-43). Trenton, NJ: Africa World Press, Inc.

Phillips, L. (Ed.) (2006). The womanist reader. New York, NY: Routledge.

Said, E. W. (1978). Orientalism. New York, NY: Pantheon Books.

Smith, L. T. (2012). Decolonizing methodologies: Research and indigenous peoples (2nd ed.). London, UK: Zed Books

Spelman, E. V. (1988). Inessential woman: Problems in exclusion in feminist thought. Boston, MA: Beacon.

ROSELYN BANDA, $\mathrm{PhD}$, is an adjunct professor of Education and Women, Gender and Sexuality Studies. She is very passionate about transnational feminist issues and her research focuses specifically on epistemological validation of women from Africa studying in the U.S. Email: bandark@miamioh.edu 